\title{
The Impact of Public School Enrolment on Child Labor in Punjab, Pakistan
}

\section{Hamna Ahmed ${ }^{*}$}

\begin{abstract}
This paper investigates the causal impact of public school enrolment on child labor. Our main hypothesis is as follows: Is school enrolment a substitute for child labor? Recognizing that schooling and work choices are jointly determined by parents in a utility maximizing framework, the study applies an instrumental variable solution to the problem of simultaneity. This approach entails using the receipt of free textbooks and access to a public primary facility as instruments for public school enrolment. Using data from the Multiple Indicator Cluster Survey for 2007/08, our working sample consists of children between 5 and 14 years of age, which makes up 25 percent of the surveyed population. The results suggest that public school enrolment can be used as a substitute for child labor. On average, a 1 percentage point increase in a household's enrolment ratio has the potential to reduce the number of hours of paid labor by almost 5 percentage points, ceteris paribus. This substitutability is highest among poor, urban, male children. Moreover, the incidence of child labor is higher among larger poor families.
\end{abstract}

Keywords: Child labor, school enrolment, instrumental variable, tobit, fixed effects, education subsidy, Pakistan.

JEL Classification: F66.

\section{Introduction}

Child labor poses a serious challenge for many developing countries, including Pakistan. Other than on humanitarian grounds, it is also undesirable from an economic point of view-it comes at the cost of long-term human capital development. In developing economies-often highly populous but resource-stricken-an improvement in the quality of human capital can prove to be an engine of growth. The development of this asset, however, depends critically on the education of the future work force. However, if parents (as rational agents) prefer work over school for their children, at the micro-level, this will perpetuate poverty by lowering

\footnotetext{
* Senior Research and Teaching Fellow, Centre for Research in Economics and Business (CREB), Lahore School of Economics.
} 
the individual's future value-adding and income generating potential (Glewwe, 2002), trapping the household in a vicious intergenerational cycle of poverty (Baland \& Robinson, 2000) (see Figure B1, Appendix B).

In a less extreme scenario where parents combine their children's work with school-the case where either work or school comes out of the child's leisure time-work will still have an adverse impact on the child's learning and, hence, affect the quality of human development. For example, children may miss school (or after-school tutorials) because of work or utilize the time designated for homework for the purpose of work. It has also been argued that work outside the house has a substantial negative impact on learning achievements, attributed mainly to the child's exhaustion and general "diversion of interest away from academic concerns" (Heady, 2003). At the macro-level, child labor possibly limits the economy's growth potential, owing to a low-skilled labor force (Krueger, 1996). Therefore, since any form of child labor before the completion of compulsory education comes at a cost to human capital development, it is considered undesirable (International Labour Organization [ILO]'s Minimum Age Convention, 1973).

Various strategies have been adopted to minimize child labor. Imposing legal restrictions is one option that has been used successfully in some developed countries (Angrist \& Krueger, 1991). Hort (1989) provides evidence for decreased child labor following legal restrictions imposed on the cotton industry in Manchester, England. Acemoglu and Angrist (1999) find, that in the US, children living in states with child labor laws are likely to stay in school longer than those in states without child labor laws. Types of legal restrictions include a ban on child labor, minimum age-of-work laws, and compulsory schooling. While compliance with legal restrictions has been witnessed in developed countries, it has failed to achieve the desired goals in low-income countries (Krueger, 1996). This limited success has been attributed to problems of enforceability, particularly in rural areas (Ravallion \& Wodon, 2000).

The limitations of imposing legal restrictions have induced policymakers in developing countries to look for policy alternatives. One such approach is the use of educational subsidies to lower schooling costs, increase school enrolments, lower dropout rates, and possibly also reduce child labor; for example, the Bolsa Escola, the Brazilian Child Labor Eradication Program, the Mexican Program for Education, Health and Nutrition, and Bangladesh's Food-for-Education program. 
The validity of the use of educational subsidies to reduce child labor is based on the underlying premise that schooling competes with child labor activities. If, however, increases in schooling come from the child's leisure time, these incentives may not be effective in reducing child labor. Ravallion and Wodon (2000) conclude that while Bangladesh's Foodfor-Education program increased school enrolment, it did not lead to a large reduction in child labor. Therefore, from a policy point of view, it is important to investigate whether school enrolment has the potential to displace child labor. Only if this is so can the use of such subsidies be justified as a tool for reducing child labor.

In this context, this paper aims to study the causal impact of school enrolment on child labor in Punjab, Pakistan. Our main hypothesis is as follows: To what extent is school enrolment a substitute for child labor? The study's methodology entails using a unique tehsil fixed effectsinstrumental variable Tobit (TFE-IVT) estimator that controls for simultaneity, unobserved tehsil heterogeneity, and a 'corner solution dependent variable.'

The remainder of the paper is organized as follows: Section 2 provides a brief review of the literature on child labor and schooling. Section 3 describes the data used and presents some basic statistics on the incidence of child labor and enrolment in Punjab. Section 4 discusses the methodology and puts forth an empirical framework. Section 5 presents our results while Section 6 concludes the study.

\section{Literature Review}

\subsection{A Definition of Child Labor}

There is a lack of consensus in the literature on what defines child labor (Guarcello, Kovrova, Lyon, Manacorda, \& Rosati, 2008). Child labor entails "work which is of such a nature or intensity that it is detrimental to children's schooling or harmful to their health and development"(ILO, 1998). The United Nations Children's Fund (1991) classifies child labor according to the child's age and number of hours worked per week: "Age 5-11: at least one hour of economic work or 28 hours of domestic work; Ages 12-14: at least 14 hours of economic work or 28 hours of domestic work; Ages 15-17: at least 43 hours of economic work or domestic work". Both definitions, however, have common ground: Work that is exploitative is classified as child labor (Kim, 2009). Official surveys report information on economically active children across three dimensions: (i) paid work in 
the labor market, (ii) unpaid work for a family farm or nonfarm enterprise, and (iii) unpaid domestic work. There are competing views on the types of work that should be included in child labor.

Proponents of the broader definition argue that domestic and family work is undesirable to the extent that it conflicts with school attendance. Moreover, certain household chores such as cooking over an open fire and baby care may be dangerous and exhausting, diverting the child's attention from educational concerns (Heady, 2003).

Advocates of the narrower definition exclude unpaid domestic and family work from the rubric of child labor (Rodgers \& Standing, 1981; Bequelle \& Boyden, 1988; Blanc, 1994). They argue that these two types of work tend to occur under parental guidance and supervision. "Since parents are likely to be the least exacting of employers", certain types of work "appear to be no worse than good exercise and practical training" (Bhalotra \& Heady, 2003). Also, such work "equips a child with essential skills that may not be learned elsewhere, and enhances the self-esteem of the child" (Hazarika \& Bedi, 2003).

This paper takes the latter approach and considers only paid work to be child labor, mainly on two accounts. First, parents' motivation for sending a child to work may differ according to the type of work, thereby exhibiting different enrolment-elasticity according to the type of work. For instance, choosing paid work for a child is likely to be driven by financial considerations, while parents may consider family and domestic work a means of imparting essential training that might not be acquired elsewhere. In this context, parents may respond differently to policy interventions geared toward increasing school attendance and reducing child labor. Second, parents may find it easier to combine householdrelated work (domestic work or family business) with schooling in the absence of a typical employer-employee relationship. In such a case, the success of policy initiatives targeting school attendance and child labor may fail to achieve a maximum response. The tradeoff between hours worked and school attendance is likely to be most substantial in the case of paid work (Edmonds, 2007). Therefore, this study classifies only paid work under the rubric of child labor. ${ }^{1}$

\footnotetext{
${ }^{1}$ We do, however, estimate the separate relationships between school enrolment and domestic and family work using a TFE-IVT estimator. In both cases, school enrolment is insignificant as expected, a priori.
} 


\subsection{Child Labor and Schooling}

There is a substantial body of work on child labor and schooling (for reviews, see Patrinos and Psacharopoulos, 1995; Basu, 1999; Dar, Blunch, Kim, \& Sasaki, 2002; Glewwe, 2002; Kandel \& Post, 2003; Edmonds \& Pavcnik, 2005; Edmonds, 2007; Udry, 2006). This study extends the literature in this domain.

Studies can be classified into two main categories: those that directly study the link between child labor and schooling and those that indirectly investigate the child labor-schooling relationship. The first approach is based on contrasting educational outcomes across working and nonworking children. For instance, in Bolivia and Venezuela, the fail rate is higher among working children who also acquire two years' less education than children who do not work (Psacharopoulos, 1997). In Peru, however, child labor does not appear to have an adverse impact on schooling (Patrinos \& Psacharopoulos, 1997). The main criticism of these studies is that, even though work choice and schooling is jointly determined, it enters these studies as an exogenous independent variable, which is likely to bias their results.

The second line of research studies the child labor-schooling link indirectly by looking at the impact of various educational policies and school-specific characteristics on child labor. These include access to schools, school quality, and provision of educational subsidies, etc. In rural Cote d'Ivoire, school proximity reduces the incidence of child labor but is not statistically significant in urban areas (Patrinos, 1999). Schooling costs have a significant impact, however, on child labor force participation in urban Bolivia (Cartwright \& Patrinos, 1999). This inverse relationship between school-related characteristics and child labor is also confirmed for Columbia and Tanzania (Akabayashi \& Psacharopoulos, 1999; Cartwright, 1999). For Pakistan, Hazarika and Bedi (2003) find that schooling costs are positively related with extra-household work but insignificant in explaining intra-household work.

More recently however, Ravallion and Wodon (2000) argue that there is not necessarily a one-to-one relationship between hours worked and school attendance. They show for Bangladesh that increases in schooling may come out of a child's leisure time and that therefore, while educational incentives may increase school attendance, they do not necessarily reduce child labor. Similarly, Akabayashi and Psacharopoulos 
(1999) conclude that school quality has had an insignificant impact on the incidence of child labor in Tanzania.

In the context of this empirical ambiguity concerning child labor and schooling, it becomes important to address the following questions: Does schooling have the potential to displace child labor? What is the degree of substitutability between hours worked and school attendance? Unlike Hazarika and Bedi (2003) who employ an indirect approach to examine the link between child labor and schooling, this study attempts to analyze the direct causal impact of school enrolment on child labor. This entails using the receipt of free textbooks and access to a public primary school facility as instruments for school enrolment while controlling for unobserved tehsil heterogeneity and a corner solution dependent variable.

The nature of the dataset we have used distinguishes this study from other studies on child labor in Pakistan. Prior work on the subject in Pakistan constitutes either case studies (Khan, 2001; Chaudhry \& Khan, 2002) or is based on household survey datasets that are rather dated. Ray (2000), Bhalotra and Heady (2003), and Hazarika and Bedi (2003) use data from the Pakistan Integrated Household Survey (PIHS) for 1991. Burki and Fasih (1998) and Rosati and Rossi (2003) employ data provided by the Child Labor Survey conducted in 1996 by the Federal Bureau of Statistics in collaboration with the Ministry of Labour, Manpower and Overseas Pakistanis, and the ILO.

This study uses the latest round of the Multiple Indicator Cluster Survey (MICS) for 2007/08, which helps extrapolate more recent estimates of the incidence of child labor and enrolment in Punjab, Pakistan. This is the first dataset on Pakistan that is representative at the tehsil level, ${ }^{2}$ making it possible to control for tehsil-level effects. Compared to the PIHS (4,795 households and 36,109 individuals) and the Child Labor Survey (10,453 households and 77,684 individuals), the MICS dataset comprises a much larger sample (91,075 households and 594,802 individuals). Using this dataset, therefore, has the dual advantage of providing a comprehensive, in-depth analysis as well as substantially increasing the explanatory power of the results yielded by the larger sample.

\footnotetext{
2 Pakistan comprises four provinces, of which Punjab is the largest in terms of population and the second largest in terms of area. Each province is divided into districts, which are subdivided into tehsils. Punjab has 36 districts and 143 tehsils in all.
} 


\section{Data}

The MICS for 2007/08 spans 91,075 households across Punjab and is, as mentioned above, representative at the tehsil level. Out of a total surveyed population of 594,802, 25.2 percent fall in the 5-14 years age bracket. Compared to urban areas, almost twice the population resides in rural areas (Table A1, Appendix A). It is worth mentioning that, even though we have focused on paid child labor, we present basic statistics on the incidence of domestic and family work (Figures B2 and B3, Appendix B) to give a snapshot of the incidence of child work across these dimensions.

The working sample constitutes 59,993 households with at least one child in the 5-14 years age bracket. Of these, 3.3 percent report the incidence of paid child labor. A comparison of households with and without child labor reveals that school enrolment is lower in those households that engage in paid child labor. They also receive a smaller amount of books on average and are poorer than those households that do not engage in child labor (Table 1).

Table 1: Descriptive statistics by work status

\begin{tabular}{lcccc}
\hline & \multicolumn{2}{c}{$\begin{array}{c}\text { Household* with paid } \\
\text { child labor }\end{array}$} & $\begin{array}{c}\text { Household without paid } \\
\text { child labor }\end{array}$ \\
\cline { 2 - 5 } Variable & Mean & Std. dev. & Mean & Std. dev. \\
\hline Enrolment ratio & 0.32 & 0.38 & 0.45 & 0.44 \\
Receives books & 0.07 & 0.25 & 0.11 & 0.31 \\
Primary facility access & 0.86 & 0.35 & 0.87 & 0.34 \\
Wealth score & -0.22 & 0.99 & -0.04 & 0.98 \\
Land ownership & 0.24 & 0.43 & 0.34 & 0.48 \\
Land area & 6.28 & 12.70 & 7.61 & 28.05 \\
Head's education & 1.91 & 1.30 & 2.32 & 1.45 \\
Head gender & 0.95 & 0.22 & 0.95 & 0.21 \\
Males < 0-4 & 0.43 & 0.68 & 0.44 & 0.69 \\
Females $<0-4$ & 0.41 & 0.66 & 0.43 & 0.69 \\
Age ratio & 1.10 & 0.90 & 0.78 & 0.86 \\
Gender ratio & 0.80 & 0.90 & 0.80 & 0.91 \\
Residential location & 0.43 & 0.50 & 0.34 & 0.47 \\
N & \multicolumn{2}{c}{58,001} \\
\hline
\end{tabular}

Source: MICS (2007/08) and author's calculations.

\footnotetext{
${ }^{3}$ The wealth index ranges between -2 and +2 . Details on how it has been constructed are given in Table A2, Appendix A.
} 
Even though the number of children engaged in paid labor is higher in rural areas, on average child laborers work longer hours in urban settings. Additionally, the mean number of paid child labor hours is higher among males (Table 2). We test these differences in average working hours across gender and regional groups more formally using the t-test. Across gender, the results show that the difference in average hours for all three categories of work (i.e., paid, domestic, and family) is statistically different from 0 at a 1 percent significance level. Across region, the difference in average number of hours spent on paid and domestic work is statistically significant, but for family work it is insignificant.

Table 2: Mean child labor hours ${ }^{4}$ (weekly)

\begin{tabular}{|c|c|c|c|c|c|c|}
\hline & Paid work & Difference & $\begin{array}{c}\text { Domestic } \\
\text { work }\end{array}$ & Difference & $\begin{array}{c}\text { Family } \\
\text { work }\end{array}$ & Difference \\
\hline Total & 25.4 & & 7.5 & & 11.4 & \\
\hline Males & 26.8 & & 7.0 & & 12.0 & \\
\hline Females & 23.2 & & 7.9 & & 10.3 & \\
\hline Rural & 24.6 & **** & 7.8 & $: * *$ & 11.3 & IS \\
\hline Urban & 26.3 & & 6.6 & & 12.6 & \\
\hline
\end{tabular}

Note: ${ }^{* *}, * *$, and $*$ indicate significance at $1 \%, 5 \%$, and $10 \%$, respectively. NS $=$ not significantly different from 0 .

Source: MICS (2007/08) and author's calculations.

Table 3 below shows that the incidence of child labor increases substantially with age.

\footnotetext{
${ }^{4}$ Avg Working hrs $=\sum t_{\text {hrs }} / \sum t^{n}$

where $t$ represents the type of work, i.e., paid, domestic, or family. For each type of work, the numerator measures the total number of hours worked while the denominator measures the total number of children engaged in that category. For example, in the case of males, the numerator measures the total number of hours that male children engage in paid work divided by the number of male working children.
} 
Table 3: Profile of working children by type of work ${ }^{5}$

\begin{tabular}{lcccccc}
\hline & $\begin{array}{c}\mathbf{( 1 )} \\
\text { Total } \\
\text { population } \\
\text { Profile of children }\end{array}$ & $\begin{array}{c}\text { (2) } \\
\text { Engaged in } \\
\text { somestic } \\
\text { work (\%) }\end{array}$ & $\begin{array}{c}\text { (3) } \\
\text { Engaged in } \\
\text { family } \\
\text { work (\%) }\end{array}$ & $\begin{array}{c}\text { (4) } \\
\text { Engaged in } \\
\text { paid work } \\
\mathbf{( \% )}\end{array}$ & $\begin{array}{c}\text { (5) } \\
\text { Currently } \\
\text { attending } \\
\text { school (\%) }\end{array}$ \\
\hline $5-14$ & Total & 150,101 & 52.0 & 3.8 & 2.3 & 73.9 \\
& Males & 77,811 & 51.1 & 4.9 & 2.7 & 76.9 \\
& Females & 72,290 & 52.9 & 2.7 & 1.9 & 70.7 \\
& Urban & 48,894 & 46.7 & 1.6 & 3.6 & 84.6 \\
$5-9$ & Rural & 101,207 & 54.5 & 4.9 & 1.9 & 68.7 \\
\hline 14 & Total & 76,725 & 40.9 & 2.1 & 1.5 & 73.2 \\
\hline
\end{tabular}

Source: MICS (2007/08) and author's calculations.

As for the profile of children in and out of school vis-à-vis paid child labor, the incidence is 7.7 percent higher among out-of-school children than among their counterparts in school (Figure 1). This is also true across gender, and more so for males-the incidence of paid child labor is approximately 13 percent higher among out-of-school children than among male children in school.

Figure 1: School Attendance and Paid Work ${ }^{6}$ (5-14)

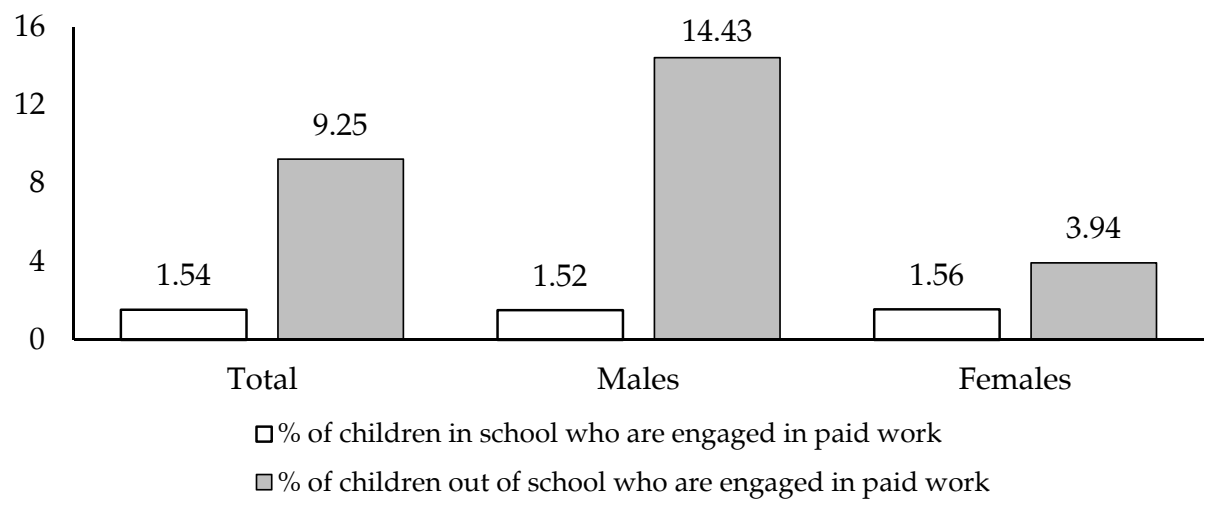

Source: Data from MICS (07-08) E author's own calculations

\footnotetext{
${ }^{5}$ Figures in columns 2-4 of Table 3 are calculated as follows: $=\sum t^{\text {number of children working }} / \sum$ total children

where $t$ represents the type of work, i.e., paid, domestic, or family. For each type of work, the numerator measures the total number of children (between 5 to 14 years) engaged in that work type while the denominator measures the total number of children between 5 and 14 years of age. For example, in the case of paid work, the numerator measures the total number of children engaged in paid work divided by the number of children between 5 and 14 years of age.

${ }^{6}$ See Table A2, Appendix A, for details of how these percentages have been calculated.
} 
Table 4 sheds light on the dynamics between child labor, wealth, and enrolment.

Table 4: Mean enrolment across wealth quintiles (\%)

\begin{tabular}{lcccc}
\hline $\begin{array}{l}\text { Wealth } \\
\text { quintile }\end{array}$ & $\begin{array}{c}\text { Public school } \\
\text { enrolment } \\
\text { (PSE) }^{7}\end{array}$ & $\begin{array}{c}\text { PSE in the } \\
\text { presence of } \\
\text { paid work }\end{array}$ & $\begin{array}{c}\text { PSE in the absence of } \\
\text { paid work }\end{array}$ & $\begin{array}{c}\text { Private school } \\
\text { enrolment }\end{array}$ \\
\hline 1 (Lowest) & 39.5 & 26.6 & 40.1 & 4.1 \\
2 & 54.4 & 38.9 & 54.9 & 13.2 \\
3 & 53.8 & 37.9 & 54.3 & 25.9 \\
4 & 43.0 & 32.4 & 43.3 & 39.7 \\
5 & 27.1 & 24.6 & 27.1 & 48.6 \\
(Highest) & & & & \\
\hline
\end{tabular}

Source: MICS (2007/08) and author's calculations.

On average, public school enrolment is lower among households with child labor compared to households without child labor. This is true for all wealth quintiles. Table 4 also shows that public school enrolment decreases while private school enrolment increases as households become richer.

In a nutshell, the raw data suggests that there might be a substitution effect between child labor and schooling in Punjab (Figure 1). Moreover, the substitution effect between child labor and schooling may be strongest in low-income rather than high-income households (Table 4).

The observations stated in this section are casual inferences from the data and warrant a rigorous econometric analysis. The precise framework for doing so is the topic of the next section.

\section{Methodology}

\subsection{Empirical Framework}

The objective here is to outline an empirical model that measures the impact of a change in school enrolment on child labor while controlling for household characteristics and unobserved tehsil-level heterogeneity. The sample consists of all households with at least one child going to a government school in the 5-14-year age bracket.

7 PSE is calculated by dividing the number of children (aged between 5 and 14 years) going to public schools divided by the total number of children aged between 5 and 14 years of age. 
Let

$$
Y_{i t}=f\left(X_{1 i t}, X_{2 i t}, \ldots X_{n i t}, Z_{1 t}, Z_{2 t}, \ldots Z_{m t}\right)
$$

where $Y$ represents the incidence of child labor in household $8 i$, tehsil $t$; the $X$ terms represent $n$ number of household-specific characteristics; and the $Z$ terms are tehsil dummies to account for tehsil fixed effects, which are $m$ in all.

Based on equation (1), we develop the following multivariate regression model.

$$
y_{i t}^{P}=\gamma+\beta_{1} S_{i t}+\sum_{\mathrm{j}=1}^{\mathrm{n}} \mathrm{X}_{\mathrm{jit}} \beta_{\mathrm{j}}+\sum_{\mathrm{k}=1}^{\mathrm{m}} \mathrm{Z}_{\mathrm{kt}} \alpha_{\mathrm{k}}+\varepsilon_{\mathrm{it}}
$$

Where

$$
\varepsilon_{i t}=\mathrm{\eta}_{t}+\mathrm{\eta}_{i t}
$$

$y_{i t}^{P}$ is the average number of hours worked in the past week in household $i$, tehsil $t$, and $y_{i t}^{P}$, where a value of 0 implies that none of the children in that household are engaged in child labor.

$S_{i t}$ is the variable of interest-a measure of children's schooling in a household and is given by the number of children attending public schools as a ratio of the total number of children less those going to private schools in the relevant age bracket (see Section 4.2.1 for a discussion on why the sample is restricted to government schools). The next section describes how this variable is treated in order to estimate the empirical model given by equation (2).

$\beta_{1}$ measures the ceteris paribus impact of a change in school enrolment on the incidence of child labor, while controlling for household$(X)$ and tehsil-specific characteristics $(Z)$.

$\gamma$ is the intercept, $\beta$ and $\alpha$ are vectors of parameters, and $\varepsilon_{i t}$ is a vector of normally distributed error terms. The error terms are based on two components as shown by equation (3). $\eta_{t}$ represents unobserved tehsilspecific characteristics that are common to all households in a particular

${ }^{8}$ We specify a household-level rather than individual-level model because data on distance from school facility and on receipt of textbooks was not available on a child-by-child basis. Since both these variables are used as instrumental variables for schooling, data limitations permitted only a household rather than an individual-level analysis. 
tehsil (capturing factors such as societal attitude and perceptions of schooling). $\eta_{i t}$ captures unobservable household-specific characteristics such as parents' motivation and willingness to school their children, etc.

Further details on how these variables have been computed are given in Table A2, Appendix A.

\subsection{Estimation Strategy}

The empirical model specified in equation (2) suffers from a simultaneity bias, which occurs because the variable of interest, school enrolment, is jointly determined with the dependent variable, child labor. Parents will simultaneously determine the optimal mix of work and schooling for their children so as to maximize the household's utility function. The key identification condition required to estimate equation (2) by ordinary least squares (OLS) is given by:

$$
\operatorname{Cov}(X, \varepsilon)=0
$$

Simultaneity violates the identification condition (4). Therefore, applying OLS under simultaneity will produce biased and inconsistent estimators.

Even under simultaneity, equation (2) can be estimated consistently using the instrumental variable (IV) approach. We propose using the receipt of free textbooks $\left(B_{i t}\right)$ by the household and access to a primary government school facility ${ }^{9}\left(A_{i t}\right)$ as an instrument for average government school enrolment $\left(S_{i t}\right)$ in the household. It is worth mentioning that access to a public middle school facility was also considered as a potential instrument for enrolment. However, it exhibited a low correlation with public school enrolment, which is not surprising as one would expect that, as children grow older, access in terms of distance to school is likely to become a less important consideration.

Within the sample under study, free textbooks reached 6,926 households, i.e.. 11.6 percent of the total, while 87 percent of the households had access to a public primary school facility.

\footnotetext{
${ }^{9}$ The rationale underlying the use of 'distance to a government school facility' as an instrument for school enrolment is that it is highly correlated with enrolment but independent of hours worked in each household. Moreover, it is exogenous to the household's decision-making process.
} 


\subsubsection{Instrument Validity}

For these instruments to be valid, the following conditions must be satisfied:

$$
\begin{aligned}
& \operatorname{Cov}\left(I_{i t}, i t\right)=0 \\
& \operatorname{Cov}\left(I_{i t}, S_{i t}\right) \neq 0
\end{aligned}
$$

where $I_{i t}=B_{i t}$ and $A_{i t}$

A fair amount of correlation between $\left(S_{i t}\right)$ and $\left(A_{i t}\right)$, as well as between $\left(S_{i t}\right)$ and $\left(B_{i t}\right)$ provides evidence in support of condition (6) (see Table A4, Appendix A).

Condition (5) requires that the chosen instruments should not affect the incidence of child labor other than through their impact on average public school enrolment in the household.

The disbursement mechanism for distributing these textbooks was such that books would be transported from the Punjab Textbook Board in the provincial capital, Lahore, to district headquarters, to tehsil warehouses, and on to union councils, where it was the latter's responsibility to distribute the books to all government schools in that area. Once the schools received the books, they were passed on to all students enrolled in that school and became their property. Since free books were provided only by government schools, we have restricted our scope of analysis to public school enrolment (see Appendix C for further details on the textbook project and its disbursement mechanism under the Punjab Education Sector Reform Package [PESRP]).

About 56 percent of all households have at least one child aged between 5 and 14 years attending a government school. Given the disbursement mechanism and assuming a perfectly efficient system, all these households should have received free books. In practice, however, only 20 percent of the households with at least one child enrolled in a public school benefited from the textbook subsidy.

In order to ensure the validity of the instrument, it is important to explore whether there is a systematic pattern among the households that benefited from the subsidy. For instance, are households in poor districts more likely to benefit from the subsidy? Are households on the periphery (i.e., further away from the provincial capital) less likely to receive books 
than those households at the core (i.e., close to the provincial capital)? If so, the receipt of books will not serve as an appropriate instrument. Figure 2 illustrates the percentage of households receiving free books in each tehsil (measured on the y-axis) against average tehsil wealth ${ }^{10}$ (on the $\mathrm{x}$-axis), while Figure 3 shows the distance between each district and the provincial capital on the $x$-axis and the percentage of households receiving free books in each tehsil on the $y$-axis. ${ }^{11}$ Both figures suggest that there is no systematic pattern in the receipt of free textbooks across the tehsils under study. ${ }^{12}$

\section{Figure 2: Receipt of books and average wealth}

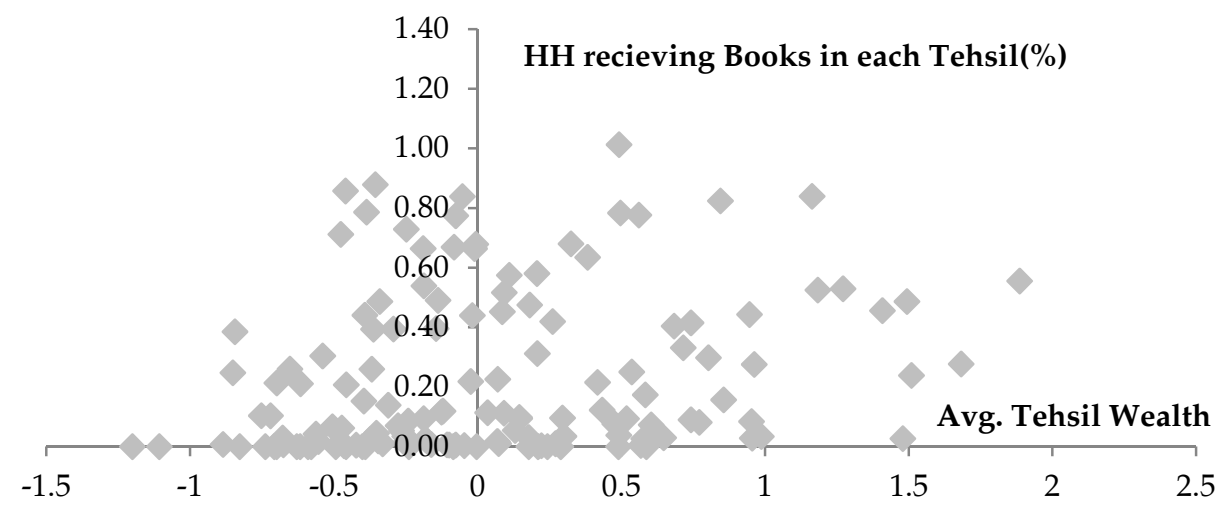

${ }^{10}$ We calculate average tehsil wealth by aggregating the individual wealth of each household within the tehsil and dividing it by the number of households surveyed in that tehsil. See Table A2, Appendix A, for details of how the individual household-level wealth index is created.

${ }^{11}$ The straight lines that emerge in Figure 3 are due to the fact that the distance between the district headquarters and the provincial capital is used as a proxy for the distance between each tehsil and the capital.

${ }^{12}$ A further test for ascertaining whether there is a systematic relationship between the percentage of households receiving textbooks and its average wealth and distance from the provincial capital is to regress the ratio of households separately on average tehsil wealth and on the distance from the provincial capital. Both regressions yielded a very low R-squared ranging between 1 and 2 percent. 


\section{Figure 3: Receipt of books and distance from provincial capital}

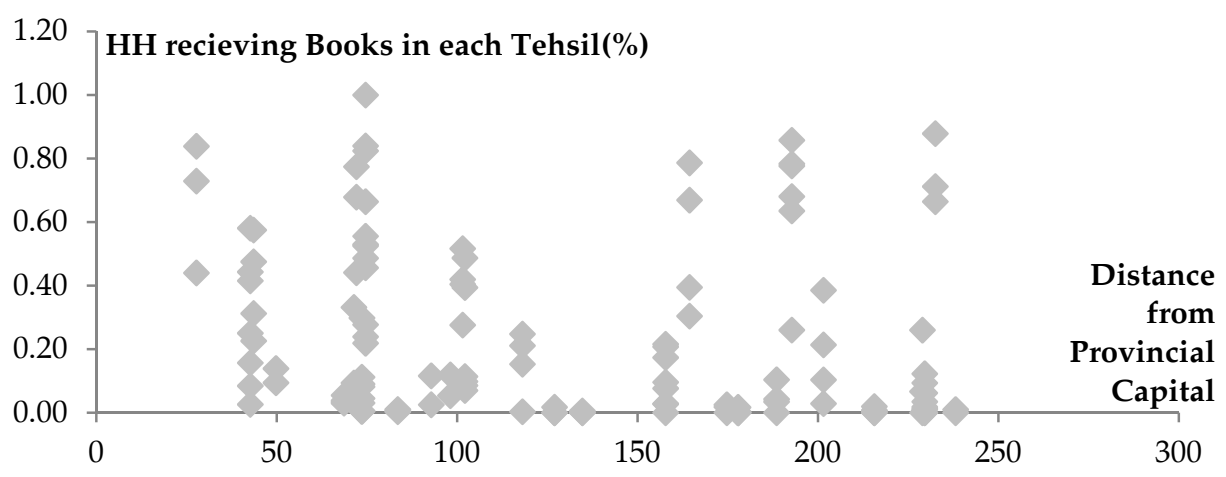

To further assess the validity of the instruments, we conduct a test for over-identification restrictions (see also Section 5.1).

Given that conditions (5) and (6) are satisfied, equation (2) can be estimated in two stages. The first stage entails specifying a reduced-form equation for schooling ), which is a function of ) and ) as well as all other exogenous variables. This equation is given by:

$$
S_{i t}=\pi_{0}+\pi_{1} B_{i t}+\pi_{2} A_{i t}+\sum_{j=a}^{n} X_{j i t} \pi+\sum_{k=1}^{m} Z_{k t} \gamma_{k}+\mu_{i t}
$$

where the error term is normally distributed and each explanatory variable is uncorrelated with the error. A final identification condition for ) and ) to be valid instruments for schooling is given by:

$$
\pi_{1} \neq 0 \text { And } \pi_{2} \neq 0
$$

The second stage involves estimating equation (2) after replacing ) with its fitted values obtained from equation (7).

Typically, OLS would be used to estimate the reduced form, equation (7), and the structural equation, equation (2), where ) has been replaced with its fitted values. In this case, however, the distribution of the dependent variable is such that it bars the use of OLS as an appropriate estimation technique.

The model outlined in equation (2) is a classic case of a corner solution model. Since child labor is only prevalent in 3.3 percent of households, the dependent variable is "continuous over strictly positive values, but equals zero for a non-trivial part of the population. It is problematic to use OLS under such a setting," (Woolridge, 2002, pp. 545- 
550). To circumvent the issue of a cornered dependent variable, we use a Tobit maximum likelihood estimator (TMLE).

The validity of a TMLE, however, depends critically on two assumptions: the normality and homoskedasticity of the underlying distribution. The quintile-quintile plot in Figure 4 closely follows the quintiles of a normally distributed dataset, thus implying that normality holds for the data at hand. Homoskedasticity is, however, likely to be violated. Therefore, we employ robust standard errors to control for heterogeneity.

Figure 4: Quintile-quintile normality plot

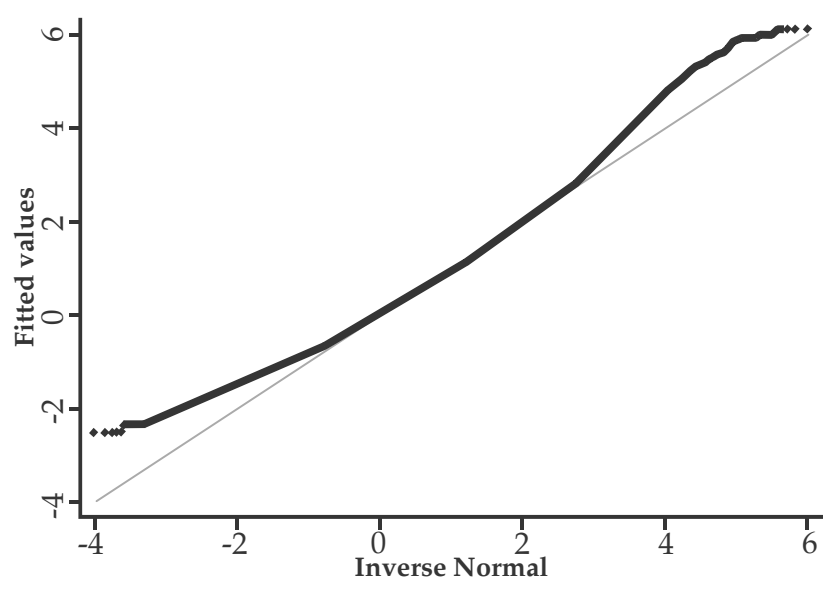

As a robustness check of the TMLE, we also estimate a probit model whereby the dependent variable equals 1 for households in which child labor is prevalent and 0 otherwise. ${ }^{13}$ The probit and Tobit estimates are quite similar in terms of sign and magnitude, thus supporting the use of the TMLE.

A final concern with the model outlined in equation (2) is the unobserved tehsil-specific effect, $\eta_{t}$, as shown in equation (3). This effect may be correlated with some of the explanatory variables, thus violating the key identification condition outlined in (4). To deal with this issue, we control for unobservable tehsil heterogeneity by employing TFE estimation, ${ }^{14}$ which will purge the correlation between $(X)$ and $\left(\eta_{t}\right)$.

${ }^{13}$ The results are not shown here but are available on request.

${ }^{14}$ Given the large number of tehsils in Punjab (143 in all), estimating the model with TFE would imply adding 142 dummies to the variable of interest and the requisite controls on the right-hand side. In spite of so many fixed-effects dummies, the Tobit estimation remains consistent due to the large sample size of almost 33,000 households. 
Recapitulating, the estimation technique has three dimensions: the use of (i) instruments to control for simultaneity, (ii) TFE to control for unobserved tehsil heterogeneity, and (iii) TMLE to control for a corner solution dependent variable. Putting these together yields a unique TFEIVT estimator with which to study the relationship between average public school enrolment and child labor across Punjab in Pakistan.

\section{Results and Discussion}

\subsection{First-Stage Results}

The first-stage results are given in Table A3, Appendix A, and show that both receipt of the subsidy as well as access to a public school facility have a significant and positive effect on the percentage of children enrolled in public schools. In addition, the public school enrolment ratio decreases in richer households, implying that wealthier parents are less likely to send their children to public schools. On average, enrolment ratios are higher in households with literate parents. Moreover, as the number of older children (those in the 10-14-year age bracket) increases relative to the number of children in the 5-9-year age bracket, the public school enrolment ratio increases. This is not surprising given that there are limited private schooling options at higher tiers of schooling. ${ }^{15}$

\subsection{Second-Stage Results}

The TFE-IVT estimates are similar to the OLS estimates in terms of signs and statistical significance (Table 5). ${ }^{16}$ The magnitude of the TFE-IVT estimates is far stronger, but a comparison of magnitudes per se is not plausible because the coefficients represent the marginal effects on the latent dependent variable for the whole sample, i.e., $y_{i t}^{P} \geq 0$.

\footnotetext{
15 Andrabi, Das, Khwaja, Vishwanath, and Zajonc (2007) have documented that the massive growth in private schools in Punjab in the past decade has predominantly been at the primary level. ${ }^{16}$ As a robustness check, the model was rerun using total enrolment (including private school-going children). The results were similar to those obtained for public school enrolment alone (results available on request). The subsidy could have two possible effects on enrolment. First, by reducing the cost of schooling, it may free up resources, allowing parents to send more children to school. This could result in an increase in public school enrolment, in private school enrolment, or both. Second, the subsidy may reduce the cost of public relative to private schooling, incentivizing parents to shift their children from private to public schools. The similarity of results with those for public school enrolment and total enrolment indicates that the former effect outweighs the latter in this context.
} 
Table 5: Estimates of child labor

\begin{tabular}{|c|c|c|c|c|}
\hline \multirow{2}{*}{$\begin{array}{l}\text { Dependant variable = } \\
\text { average weekly hours }\end{array}$} & \multicolumn{2}{|c|}{$\begin{array}{l}\text { OLS-IV } \\
\text { (1) }\end{array}$} & \multicolumn{2}{|c|}{$\begin{array}{l}\text { Tobit-IV } \\
\text { (2) }\end{array}$} \\
\hline & Coefficient & t-stats & Coefficient & t-stats \\
\hline Enrolment ratio & $-0.16^{* * *}$ & -5.35 & $-5.33^{* * *}$ & -5.36 \\
\hline Wealth index & $-0.051^{* * *}$ & -9.76 & $-1.39 * * *$ & -10.14 \\
\hline Landholding & $-0.037^{* * *}$ & -5.72 & $-1.12^{* * *}$ & -5.52 \\
\hline Landownership*urban & $-0.02^{* * *}$ & -4.29 & $-1.01^{* * *}$ & -4.76 \\
\hline Head's education level & $-0.01^{* *}$ & -3.2 & $-0.22^{* * *}$ & -3.10 \\
\hline Mother's education level & $-0.00^{*}$ & -2.24 & $-0.00^{*}$ & -2.34 \\
\hline Head's gender & -0.00 & -0.11 & 0.05 & -0.12 \\
\hline Family size & $0.05^{* * *}$ & 5.09 & $1.77^{* * *}$ & -6.02 \\
\hline Family size across wealth quintiles & $-0.01^{* * *}$ & 3.46 & $-0.15^{* * *}$ & 3.75 \\
\hline Gender ratio & $-0.01^{* *}$ & -3.03 & $-0.19^{* *}$ & -2.13 \\
\hline Age ratio & $0.04^{* * *}$ & 9.67 & $1.06^{* * *}$ & -11.13 \\
\hline Urban & $0.07^{* * *}$ & 7.05 & $1.88^{* * *}$ & -7.11 \\
\hline First-stage residuals & $0.00^{* *}$ & 2.19 & $0.08^{* *}$ & 2.27 \\
\hline \multicolumn{5}{|l|}{$\begin{array}{l}142 \text { tehsil dummies (included but not } \\
\text { shown here) }\end{array}$} \\
\hline Constant & $0.09 *$ & 2.08 & $-13.02^{* * *}$ & -14.05 \\
\hline $\mathrm{N}^{17}$ & 33,938 & & 33,938 & \\
\hline Log likelihood & - & & -24206.58 & \\
\hline R-squared & 0.029 & & 0.070 & \\
\hline First-stage residuals (p-values) & 0.03 & & 0.027 & \\
\hline Over-identification test ( $\mathrm{p}$-values) & 0.85 & & 0.98 & \\
\hline
\end{tabular}

Note: ${ }^{* *}, * *$, and $*$ indicate significance at $1 \%, 5 \%$, and $10 \%$, respectively.

Source: Author's calculations.

There is a substitution effect between schooling and paid child labor $^{18}$ (Table 5), which is confirmed by a statistically significant and negative TFE-IVT estimate of average public school enrolment. We expect, on average, that a 1 percent increase in a household's public school

\footnotetext{
${ }^{17}$ While the MICS is a survey of 90,000 households, only 59,993 households have at least one child between the ages of 5 and 14 years. This sample is restricted further to households with at least one child enrolled in a public school, limiting the sample to 33,938 households.

${ }^{18}$ The model was rerun using the number of average weekly hours spent carrying out 'paid, family, or domestic work', 'paid and family work', 'only family work', and 'only domestic work'. For each of these dependents, both gender- and area-disaggregated regressions were undertaken. The significant and negative relationship between enrolment and work hours continued to hold in the aggregated regressions, but the disaggregated regressions showed that schooling is insignificant in reducing hours worked at home. This is because a large percentage of children (especially females) from both the school-going as well as out-of-school-going sample engage in domestic work (this is also evident in Figure B2, Appendix B). Since school-going children combine schooling with household chores, the reduction in cost of schooling as a result of the subsidy does not have any significant impact on reducing the number of hours worked at home. The results of the disaggregated regression on domestic work also showed that the significance in the pooled regression was driven by paid and family work. Due to the large number of regressions, these results are not shown but are available on request.
} 
enrolment has the potential to reduce the number of hours of paid labor by almost 5 percentage points, ceteris paribus.

Child labor is more responsive to schooling in urban areas than rural areas (Table 6). Likewise, the degree of substitutability between child labor and schooling is stronger among males than females (Table 7). These two findings are also confirmed by rerunning an augmented version of the model, including the interaction terms between the enrolment ratio, gender ratio, and the household's rural/urban location.

Table 6: Estimates of child labor by location

\begin{tabular}{|c|c|c|c|c|}
\hline \multirow{3}{*}{$\begin{array}{l}\text { Dependent variable = } \\
\text { average weekly hours }\end{array}$} & \multicolumn{4}{|c|}{ Paid Work } \\
\hline & \multicolumn{2}{|c|}{ Urban } & \multicolumn{2}{|c|}{ Rural } \\
\hline & Coefficient & t-stats & Coefficient & t-stats \\
\hline Enrollment Ratio & $-5.34^{* * *}$ & -3.01 & $-4.68^{* * *}$ & -3.84 \\
\hline Wealth Index & $-1.71^{* * *}$ & -6.90 & $-1.23^{* * *}$ & -6.59 \\
\hline Landholding & -0.13 & -0.27 & $-1.34^{* * *}$ & -6.01 \\
\hline Head Eduation Level & $-0.41^{* * *}$ & -4.04 & -0.09 & -0.93 \\
\hline Mother's Education Level & $-0.00^{* *}$ & 2.49 & -0.00 & 1.37 \\
\hline Head Gender & -0.83 & -1.35 & 0.87 & -1.42 \\
\hline Family Size & $1.74^{* * *}$ & -3.77 & $1.70^{* * *}$ & -4.49 \\
\hline Age Ratio & $1.11^{* * *}$ & -6.56 & $1.10^{* * *}$ & -9.32 \\
\hline Gender Ratio & -0.22 & -1.49 & -0.16 & -1.42 \\
\hline \multicolumn{5}{|c|}{$\begin{array}{l}142 \text { Tehsil Dummies (included but not shown } \\
\text { here) }\end{array}$} \\
\hline Constant & $-9.89^{* * *}$ & -5.10 & $-13.63^{* * *}$ & -12.12 \\
\hline $\mathrm{N}$ & \multicolumn{2}{|c|}{11687} & \multicolumn{2}{|c|}{24926} \\
\hline Log Liklihood & \multicolumn{2}{|c|}{-7341.10} & \multicolumn{2}{|c|}{-16088.59} \\
\hline Hausman Test ( $p$ value) & \multicolumn{2}{|l|}{0.029} & \multicolumn{2}{|l|}{0.025} \\
\hline Overidentification Test ( $\mathrm{p}$ value) & \multicolumn{2}{|l|}{0.78} & \multicolumn{2}{|l|}{0.81} \\
\hline
\end{tabular}

Note: ${ }^{* *}, * * \& *$ indicate significance at $1 \%, 5 \%$ and $10 \%$ respectively.

Source: Author's calculations.

Poverty is an important factor explaining child labor. Less wealthy households in both urban and rural settings are more likely to engage in child labor (Table 5). While the result holds for males, in the case of females, a lack of wealth seems to have no bearing on the incidence of child labor (Table 7).

The positive TFE-IVT estimates for family size also corroborate the link between lack of wealth (or poverty) and child labor (Table 5). Larger families faced greater resource constraints, and therefore the average number of labor hours increase as families grow. This effect differs across wealth quintiles (Table 5). On average, larger families in the 
lowest wealth quintile work longer hours than larger households in the highest wealth quintile (Table 5).

Table 7: Estimates of child labor by gender

\begin{tabular}{|c|c|c|c|c|}
\hline \multirow{2}{*}{$\begin{array}{l}\text { Dependent variable = } \\
\text { average weekly hours }\end{array}$} & \multicolumn{2}{|c|}{ Males } & \multicolumn{2}{|c|}{ Females } \\
\hline & Coefficient & t-stats & Coefficient & t-stats \\
\hline Enrollment Ratio & $-7.57^{* * *}$ & -4.99 & $-5.84^{* *}$ & -2.50 \\
\hline Wealth Index & $-1.91^{* * *}$ & -9.17 & -0.51 & -1.61 \\
\hline Landholding & $-1.39 * * *$ & -4.55 & -0.38 & -0.89 \\
\hline Landownership*Urban & $-0.05^{* * *}$ & -3.66 & -0.02 & -0.75 \\
\hline Head Education Level & -0.07 & -0.72 & -0.00 & -0.02 \\
\hline Mother's Education Level & $-0.00^{*}$ & -1.71 & $-0.00^{* *}$ & -2.49 \\
\hline Head Gender & -0.04 & -0.06 & 1.23 & -1.06 \\
\hline Family Size & $1.73^{* * *}$ & -3.93 & 0.38 & -0.55 \\
\hline Gender Ratio & $-0.47^{* * *}$ & -2.59 & $0.41^{*}$ & -1.89 \\
\hline Age Ratio & $2.54^{* * *}$ & -14.08 & $1.11^{* * *}$ & -3.64 \\
\hline Urban & $2.55^{* * *}$ & -6.43 & $1.85^{* * *}$ & -3.26 \\
\hline \multicolumn{5}{|c|}{$\begin{array}{l}142 \text { Tehsil Dummies (included but not shown } \\
\text { here) }\end{array}$} \\
\hline Constant & $-17.58^{* * *}$ & -12.14 & $-18.68^{* * *}$ & -8.29 \\
\hline$\overline{\mathrm{N}}$ & \multicolumn{2}{|c|}{30181} & \multicolumn{2}{|c|}{19783} \\
\hline Log Likelihood & \multicolumn{2}{|c|}{-21725.80} & \multicolumn{2}{|c|}{-13970.42} \\
\hline Hausman Test ( $p$ values) & \multicolumn{2}{|c|}{0.041} & \multicolumn{2}{|c|}{0.039} \\
\hline Over-identification Test ( $\mathrm{p}$ value) & \multicolumn{2}{|l|}{0.87} & \multicolumn{2}{|l|}{0.85} \\
\hline
\end{tabular}

Note: ${ }^{* *},{ }^{* *}$, and ${ }^{*}$ indicate significance at $1 \%, 5 \%$, and $10 \%$, respectively.

Source: Author's calculations.

Land is considered a symbol of wealth in rural settings-child labor is lower among land-rich households than among land-poor households (Table 5). Land ownership is also an important determinant of male child labor-male children work less in households with land compared to those without land (Table 7). This relationship is sensitive to households' residential location-urban male children from land-rich households work fewer hours than their counterparts in rural areas (Table 7). Among females, land ownership has no bearing on the incidence of child labor (Table 7).

Households whose heads are more educated have lower average labor hours (Table 5). The incidence of child labor increases substantially with the household head's age (Tables 5, 6, and 7).

\section{Diagnostics}

The first test was undertaken to establish the endogeneity of $S$. In line with the Smith-Blundel procedure, OLS residuals were obtained from 
the reduced form of $S$, i.e., equation (7), ${ }^{19}$ and included in the Tobit of $y$ on $S, X$, and $Z$, i.e., equation (2). The t-statistic of the OLS residuals provided a simple test for the endogeneity of $S$ with the null being that $S$ is exogenous. On the basis of the p-values, we concluded that $S$ was indeed endogenous (Tables 5, 6, and 7).

Next, in order to ensure that condition (5) held, a test for overidentifying restrictions was constructed by regressing the residuals obtained from equation (2) on the instruments as well as on all other exogenous variables. On the basis of the p-values, we failed to reject the null that all the excluded variables were exogenous.

\subsection{Discussion}

In light of the results presented in the previous section, we can conclude that schooling can be used effectively to reduce child labor. Thus, schooling is important not just as an end in itself-as argued by the vast body of literature that emphasizes the need to invest in children and raise the quantity of schooling in developing countries-but it is equally important because of its positive spillover effects. Given the failure of legal restrictions on child labor and the issues of enforceability in developing countries, the use of schooling to combat child labor offers a promising yet practical approach for diverting children from work to school.

Both arguments that educational subsidies are an effective means of promoting enrolment on one hand (as documented by Chaudhury \& Parajuli, 2010, for Punjab) and that increasing school enrolment can displace child labor on the other lead to an important policy implication. The government should continue investing in programs such as the PESRP, which reduce the cost and increase the attraction of schooling. Such programs will not only have direct benefits in the form of better schooling outcomes (as has already been witnessed in the past), but will also generate positive externalities in the form of fewer child labor activities.

\section{Conclusions}

The objective of this paper was to study the causal impact of public school enrolment on child labor in Punjab, Pakistan. Our main hypothesis was: Is school enrollment a substitute for child labor? The methodology entailed using a unique TFE-IVT estimator that controlled for simultaneity,

\footnotetext{
${ }^{19}$ The first-stage results are presented in Table A3, Appendix A.
} 
unobserved tehsil heterogeneity, and a 'corner solution dependent variable.' The data used was provided by the MICS for 2007/08.

Our results suggest that school enrolment can be used as a substitute for child labor. On average, a 1 percentage point increase in a household's public school enrolment has the potential to reduce hours in paid labor by almost 5 percentage points, ceteris paribus. This substitutability is highest among poor, urban males. The incidence of child labor is higher among larger, poor families.

The results imply that schooling can be used effectively to reduce child labor. Thus, schooling is important not just as an end in itself, but also because of its positive spillover effects in the form of fewer child labor activities. This calls for the government to continue investing in programs such as the PESRP, which reduce the cost and increase the attraction of schooling.

Children offer a promising future for our country. The ability to realize that potential depends critically on the kind of skills and opportunities available to them. Education can provide the desired key to success, not only by enhancing their skills and capabilities, but also through positive externalities in the form of reduced child labor. 


\section{References}

Acemoglu, D., \& Angrist, J. (1999). How large are the social returns to education? Evidence from compulsory schooling laws. In B. S. Bernanke \& K. Rogoff (Eds.), NBER macroeconomics annual 2000 (pp. 9-59). Cambridge, MA: National Bureau of Economic Research.

Akabayashi, H., \& Psacharopoulos, G. (1999). The trade-off between child labor and human capital formation: A Tanzanian case study. Journal of Development Studies, 35(5), 120-140.

Andrabi, T., Das, J., Khwaja, A., Vishwanath, T., \& Zajonc, T. (2007). The learning and educational achievement in Punjab schools (LEAPS) report. Washington, DC: World Bank.

Angrist, J. D., \& Krueger, A. (1991). Does compulsory school attendance affect schooling and earnings? Quarterly Journal of Economics, 106(4), 979-1014.

Baland, J., \& Robinson, J. (2000). Is child labor inefficient? Journal of Political Economy, 108, 663-679.

Basu, K. (1999). Child labor: Causes, consequences, and cure, with remarks on international labor standards. Journal of Economic Literature, 37(September), 1083-1119.

Basu, K., Das, S., \& Dutta, B. (2007). Child labor and household wealth: Theory and empirical evidence of an inverted $U$ (Discussion Paper No. 2736). Bonn, Germany: Institute for the Study of Labor.

Basu, K., \& Van, P. H. (1998). The economics of child labor. American Economic Review, 88(3), 412-427.

Bequelle, A., \& Boyden, J. (Eds.). (1988). Combating child labor. Geneva, Switzerland: International Labour Office.

Bhalotra, S., \& Heady, C. (2003). Child farm labor: The wealth paradox. World Bank Economic Review, 17(2), 197-227.

Blanc, C. S. (1994). Urban children in distress: Global predicaments and innovative strategies. New York, NY: Routledge. 
Burki, A. A., \& Fasih, T. (1998). Households' non-leisure time allocation for children and determinants of child labor in Punjab, Pakistan. Pakistan Development Review, 37(4, Pt. 2), 899-914.

Cartwright, K. (1999). Child labor in Columbia. In C. Grootaert \& H. A. Patrinos (Eds.), The policy analysis of child labor: A comparative study. New York, NY: St. Martin's Press.

Cartwright, K., \& Patrinos, H. A. (1999). Child labor in urban Bolivia. In C. Grootaert \& H. A. Patrinos (Eds.), The policy analysis of child labor: A comparative study. New York, NY: St. Martin's Press.

Chaudhry, M. A., \& Khan, F. N. (2002). Economic and social determinants of child labor: A case study of Dera Ismail Khan, Pakistan. Lahore Journal of Economics, 7(2), 15-40.

Chaudhury, N., \& Parajuli, D. (2010). Conditional cash transfers and female schooling: The impact of the female school stipend program on public school enrolments in Punjab, Pakistan. Applied Economics, 42(28), 3565-3583.

Chowa, G., Ansong, D., \& Mas, R. (2010). Assets and child wellbeing in developing countries: A research review. Children and Youth Services Review, 32, 1508-1519.

Dar, A., Blunch, N., Kim, B., \& Sasaki, M. (2002). Participation of children in schooling and labor activities: A review of empirical studies (Social Protection Discussion Paper Series No. 0221). Washington, DC: World Bank.

Edmonds, E. (2007). Child labor. In J. Strauss \& T. P. Schultz (Eds.), Handbook of development economics (Vol. 4). Amsterdam, The Netherlands: North-Holland.

Edmonds, E., \& Pavcnik, N. (2005). Child labor in the global economy. Journal of Economic Perspectives, 19(1), 199-220.

Fafchamps, M., \& Wahba, J. (2006). Child labor, urban proximity and household composition. Journal of Development Economics, 79, 374397. 
Glewwe, P. (2002). Schools and skills in developing countries: Educational policies and socioeconomic outcomes. Journal of Economic Literature, 50, 436-482.

Grootaert, C. (1999). Child labor in Cote d'Ivoire. In C. Grootaert \& H. A. Patrinos (Eds.), The policy analysis of child labor: A comparative study. New York, NY: St. Martin's Press.

Grootaert, C., \& Patrinos, H. A. (1999). The policy analysis of child labor: A comparative study. New York, NY: St. Martin's Press.

Guarcello, L., Kovrova, I., Lyon, S., Manacorda, M., \& Rosati, F. (2008, November). Towards consistency in child labour measurement: Assessing the comparability of estimates generated by different survey instruments (Understanding Children's Work Project Working Paper Series). Retrieved on 19 December 2010 from http://www.iza.org/conference_files/childl2009/guarcello_1021.pdf

Hazarika, G., \& Bedi, A. S. (2003). Schooling costs and child work in rural Pakistan. Journal of Development Studies, 39(5), 29-64.

Hazarika, G., \& Sarangi, S. (2008). Household access to microcredit and child work in rural Malawi. World Development, 36, 843-859.

Heady, C. (2003). The effect of child labor on learning achievement. Journal of World Development, 31(2), 385-398.

Hort, B. (1989). Work, family, and the state: Child labor and the organization of production in the British cotton industry, 1780-1920. London, UK: London University Press.

International Labour Organization. (1998). Report VI (1) - Child labor: Targeting the intolerable (International Labor Conference, 86 ${ }^{\text {th }}$ session). Geneva, Switzerland: International Labour Office.

Kandel, W., \& Post, D. (2003). After school work in Mexico: Competing for children's time success. International Journal of Educational Development, 23, 299-314.

Khan, R. E. A. (2001). Socioeconomic aspects of child labor: A case study of children in auto workshops. Lahore Journal of Economics, 6(1), 93-112. 
Kim, Y.-C. (2009). Is combining child labor and school education the right approach? Investigating the Cambodian case. International Journal of Educational Development, 29, 30-38.

Krueger, A. (1996). International labor standards and trade. In M. Bruno \& B. Pleskovic (Eds.), Annual World Bank conference on development economics (pp. 281-302). Washington, DC: World Bank.

Patrinos, H. A., \& Psacharopoulos, G. (1995). Educational performance and child labor in Paraguay. International Journal of Educational Development, 15, 47-60.

Patrinos, H. A., \& Psacharopoulos, G. (1997). Family size, schooling and child labor in Peru: An empirical analysis. Journal of Population Economics, 10(4), 387-405.

Psacharopoulos, G. (1997). Child labor versus educational attainment: Some evidence from Latin America. Journal of Population Economics, 10(4), 377-386.

Punjab, Department of School Education. (2011). Punjab education sector reform program. Retrieved on 14 January 2011 from http:/ / www.pesrp.edu.pk/pmiu.php?v=programs\#4

Ravallion, M., \& Wodon, Q. (2000). Does child labor displace schooling? Evidence on behavioral responses to an enrollment subsidy. The Economic Journal, 110(462), 158-175.

Ray, R. (2000). Analysis of child labor in Peru and Pakistan: A comparative study. Journal of Population Economics, 13, 3-19.

Rodgers, G., \& Standing, G. (1981). The economic roles of children: Issues for analysis. In G. Rodgers \& G. Standing (Eds.), Child work, poverty and underdevelopment. Geneva, Switzerland: International Labour Office.

Rosati, F., \& Rossi, M. (2003). Children's working hours and school enrollment: Evidence from Pakistan and Nicaragua. World Bank Economic Review, 17, 283-295.

Siddiqi, F., \& Patrinos, H. A. (1995). Child labor: Issues, causes and interventions (Human Resources and Operations Policy Working Paper No. 56). Washington, DC: World Bank. 
Solotaroff, J. (2007). South Asia region (SAR): Regional strategy update. Washington, DC: World Bank. Retrieved on 20 December 2010 from http:/ / siteresources.worldbank.org/SOUTHASIAEXT/Resources /223546-1174426445479/annex211.pdf

Udry, C. (2006). Child labor. In A. Banerjee, R. Benabou, \& D. Mookherjee (Eds.), Understanding poverty. New York, NY: Oxford University Press.

United Nations Children's Fund. (1991). The state of the world's children 1991. New York, NY: Oxford University Press.

Woolridge, J. M. (2002). Econometric analysis of cross-section and panel data. Cambridge, MA: MIT Press.

Woolridge, J. M. (2009). Introductory econometrics: A modern approach. Cambridge, MA: MIT Press. 


\section{Appendix A: Tables}

Table A1: Population profile

\begin{tabular}{llcc}
\hline & Group & Population in sample & Percentage \\
\hline $5-14$ & Total & 150,101 & $25.2^{*}$ \\
& Males & 77,811 & 51.8 \\
& Females & 72,290 & 48.2 \\
& Urban & 48,894 & 32.6 \\
& Rural & 101,207 & 67.4 \\
$5-9$ & Total & 76,725 & 51.1 \\
$10-14$ & Total & 73,376 & 48.9 \\
\hline
\end{tabular}

* Children in the 5-14-year age bracket constitute 25 percent of the total surveyed population, equal to 594,802 individuals.

Source: MICS (2007/08). 


\section{Table A2: Definitions of variables used in the model}

\begin{tabular}{|c|c|c|}
\hline \multicolumn{3}{|c|}{ Dependent variable } \\
\hline$y_{i t}^{P}$ & $\begin{array}{l}\text { Average number of } \\
\text { hours worked for pay } \\
\text { in the past week }\end{array}$ & $\begin{array}{l}\text { (Total working hours [ ] )/(total working } \\
\text { children [ ] - private school-going } \\
\text { children [ ] )*100 }\end{array}$ \\
\hline \multicolumn{3}{|c|}{ Explanatory variables } \\
\hline \multicolumn{3}{|l|}{ Variable of interest } \\
\hline$S_{\text {it }}$ & $\begin{array}{l}\text { Share of children } \\
\text { enrolled in a } \\
\text { government school }\end{array}$ & $\begin{array}{l}\text { Number of children enrolled in public } \\
\text { schools [ ]/total children [ ] }]^{*} 100\end{array}$ \\
\hline \multicolumn{3}{|l|}{ Instruments } \\
\hline $\mathrm{B}_{\mathrm{it}}$ & $\begin{array}{l}\text { Education subsidy in } \\
\text { the form of books }\end{array}$ & $\begin{array}{l}\text { Dummy variable: } \\
1=\text { household receives books, } 0 \text { otherwise }\end{array}$ \\
\hline $\mathrm{A}_{\mathrm{it}}$ & $\begin{array}{l}\text { Access to a } \\
\text { government primary } \\
\text { school facility }\end{array}$ & $\begin{array}{l}\text { Dummy variable: } \\
1=\text { a primary school facility is accessible } \\
\text { within } 2 \mathrm{~km} \text { of the household, } 0 \text { otherwise }\end{array}$ \\
\hline \multicolumn{3}{|c|}{ Household-level controls } \\
\hline $\begin{array}{l}\text { Aggregate } \\
\text { wealth index }\end{array}$ & \multicolumn{2}{|c|}{$\begin{array}{l}\text { This index captures each household's long-term wealth through } \\
\text { information on assets. The asset has been constructed through a } \\
\text { principal components analysis of the following household goods and } \\
\text { amenities (assets): number of rooms for sleeping per member; material } \\
\text { used for floor, roof, and walls of dwelling; type of cooking fuel; } \\
\text { availability of electricity, gas, radio, television, cable television, mobile } \\
\text { and nonmobile telephone, computer, Internet access, refrigerator, air } \\
\text { conditioner, washing machine, cooler, microwave oven, sewing } \\
\text { machine, iron, water filter, motorized pump, watch, bicycle, } \\
\text { motorcycle/scooter, animal-drawn cart; car or truck }\end{array}$} \\
\hline Land & \multicolumn{2}{|l|}{ Dummy variable: } \\
\hline Head's education & \multicolumn{2}{|c|}{ Measured by completed years of schooling } \\
\hline $\begin{array}{l}\text { Mother's } \\
\text { education }\end{array}$ & \multicolumn{2}{|c|}{ Measured by completed years of schooling } \\
\hline Size of household & \multicolumn{2}{|c|}{ Variable enters in logarithmic form } \\
\hline $\begin{array}{l}\text { Gender of } \\
\text { household head }\end{array}$ & \multicolumn{2}{|l|}{ Dummy variable: } \\
\hline $\begin{array}{l}\text { Location of } \\
\text { household }\end{array}$ & \multicolumn{2}{|l|}{ Dummy variable: } \\
\hline Gender ratio & \multicolumn{2}{|c|}{ Number of female children [ ]/number of male children [ ] } \\
\hline Age ratio & \multicolumn{2}{|c|}{ Number of children aged [10-14]/number of children aged [5-9] } \\
\hline \multicolumn{3}{|c|}{ Tehsil-level controls } \\
\hline \multicolumn{3}{|c|}{ Instead of specific controls, the model employs tehsil fixed effects } \\
\hline
\end{tabular}

*Where [ ] = 5-14-year age bracket. 
Table A3: First-stage results

\begin{tabular}{|c|c|c|c|c|c|}
\hline \multicolumn{6}{|c|}{ Dependent variable $=$ enrolment ratio } \\
\hline & Overall & Urban & Rural & Males & Females \\
\hline \multirow[t]{2}{*}{ Receipt of books } & $0.334^{* * *}$ & $0.364^{* * *}$ & $0.335^{* * *}$ & $0.332^{* * *}$ & $0.306^{* * *}$ \\
\hline & $(-27.79)$ & $(-25.32)$ & $(-30.52)$ & $(-26.11)$ & $(-29.55)$ \\
\hline \multirow[t]{2}{*}{ Access } & $0.78^{* * *}$ & $0.83^{* * *}$ & $0.810^{* * *}$ & $0.799^{* * *}$ & $0.801^{* * *}$ \\
\hline & $(-10.11)$ & $(-10.15)$ & $(-9.59)$ & $(-11.54)$ & $(-10.99)$ \\
\hline \multirow[t]{2}{*}{ Wealth index } & $-0.025^{* * *}$ & $-0.083^{* * *}$ & 0.007 & $-0.051^{* * *}$ & $0.010^{* *}$ \\
\hline & $(-7.37)$ & $(-15.15)$ & $(-1.59)$ & $(-12.54)$ & $(-1.99)$ \\
\hline \multirow[t]{2}{*}{ Landholding } & 0 & -0.018 & 0.002 & -0.001 & 0.003 \\
\hline & $(-0.05)$ & $(-1.62)$ & $(-0.41)$ & $(-0.24)$ & $(-0.46)$ \\
\hline \multirow[t]{2}{*}{ Head's education level } & $0.003^{*}$ & -0.003 & $0.009^{* * *}$ & 0.002 & 0.003 \\
\hline & $(-1.78)$ & $(-1.28)$ & $(-4.07)$ & $(-0.79)$ & $(-1.03)$ \\
\hline \multirow[t]{2}{*}{ Mother's education level } & $2.225^{* *}$ & $2.201^{* *}$ & $2.339^{* *}$ & $2.366^{* *}$ & $2.245^{* *}$ \\
\hline & $(-2.48)$ & $(-2.49)$ & $(-2.43)$ & $(-2.18)$ & $(-2.19)$ \\
\hline \multirow[t]{2}{*}{ Head's gender } & $0.023^{* *}$ & 0.011 & $0.034^{* *}$ & $0.027^{* *}$ & 0.008 \\
\hline & $(-2.19)$ & $(-0.66)$ & $(-2.49)$ & $(-2.14)$ & $(-0.46)$ \\
\hline \multirow[t]{3}{*}{ Family size } & $0.052^{* * *}$ & $0.075^{* * *}$ & $0.028^{* * *}$ & $0.042^{* * *}$ & $0.045^{* * *}$ \\
\hline & $(-7.19)$ & $(-6.55)$ & $(-3.08)$ & $(-4.87)$ & $(-3.8)$ \\
\hline & $(-6.69)$ & $(-5.89)$ & $(-4.17)$ & $(-4.73)$ & $(-4.46)$ \\
\hline \multirow[t]{2}{*}{ Age ratio } & $0.033^{* * *}$ & $0.054^{* * *}$ & $0.022^{* * *}$ & $0.050^{* * *}$ & $0.020^{* * *}$ \\
\hline & $(-13.16)$ & $(-12.72)$ & $(-7.27)$ & $(-12.62)$ & $(-3.87)$ \\
\hline \multirow[t]{2}{*}{ Gender ratio } & -0.001 & $0.014^{* * *}$ & $-0.009^{* * *}$ & 0.003 & $0.006^{*}$ \\
\hline & $(-0.65)$ & $(-3.92)$ & $(-3.38)$ & $(-0.79)$ & $(-1.83)$ \\
\hline \multirow[t]{2}{*}{ Area } & $-0.102^{* * *}$ & & & $-0.115^{* * *}$ & $-0.099 * * *$ \\
\hline & $(-17.02)$ & & & $(-16.02)$ & $(-10.66)$ \\
\hline \multicolumn{6}{|c|}{142 tehsil dummies (included but not shown here) } \\
\hline \multirow[t]{2}{*}{ Constant } & $0.136^{* * *}$ & $0.260^{* * *}$ & $0.166^{* * *}$ & $0.176^{* * *}$ & $0.165^{* * *}$ \\
\hline & $(-5.62)$ & $(-4.42)$ & $(-6.11)$ & $(-5.91)$ & $(-4.32)$ \\
\hline Observations & 36613 & 11687 & 24926 & 30181 & 19783 \\
\hline
\end{tabular}

Note: $\mathrm{t}$-statistics are given in parentheses. ${ }^{* * *}, * *$, and $*$ indicate significance at $1 \%, 5 \%$, and $10 \%$, respectively. 


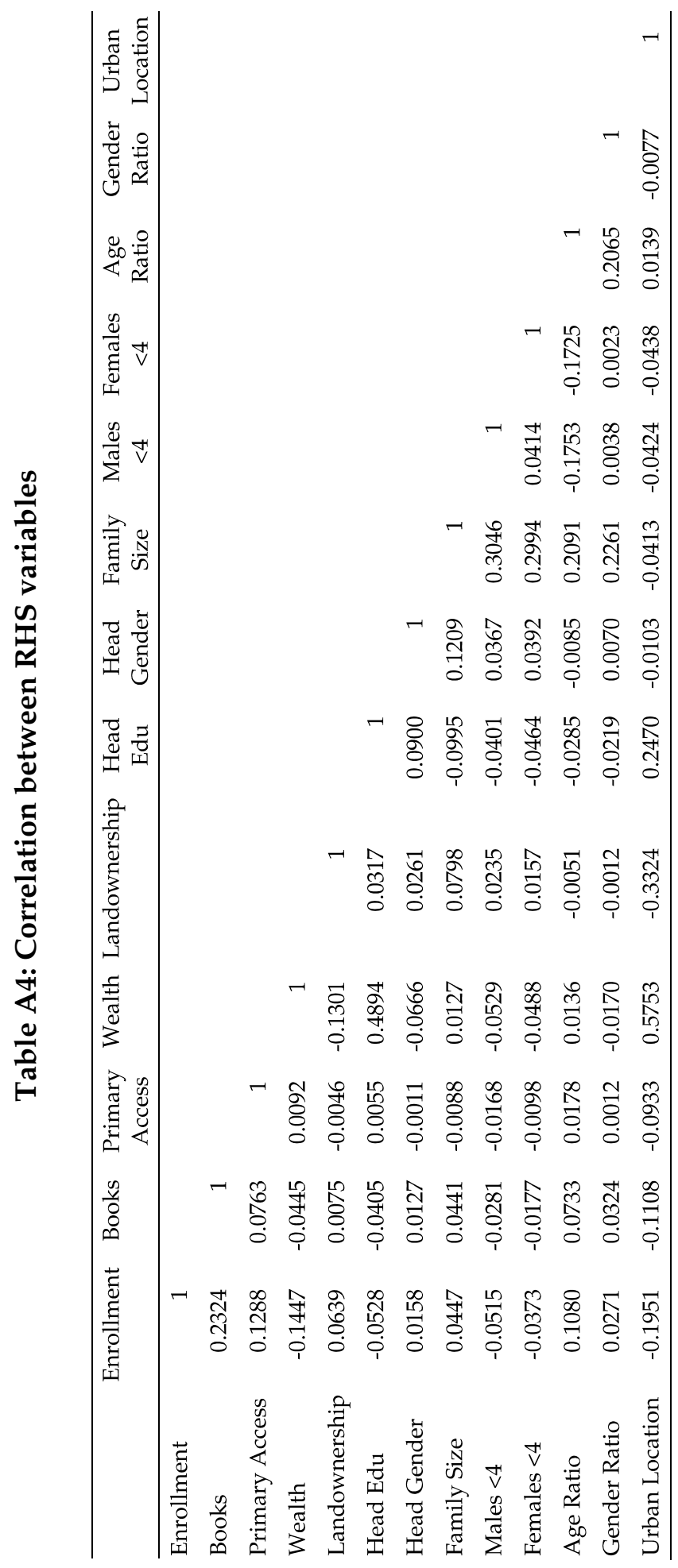




\section{Appendix B: Figures}

Figure B1: Intergenerational child labor trap

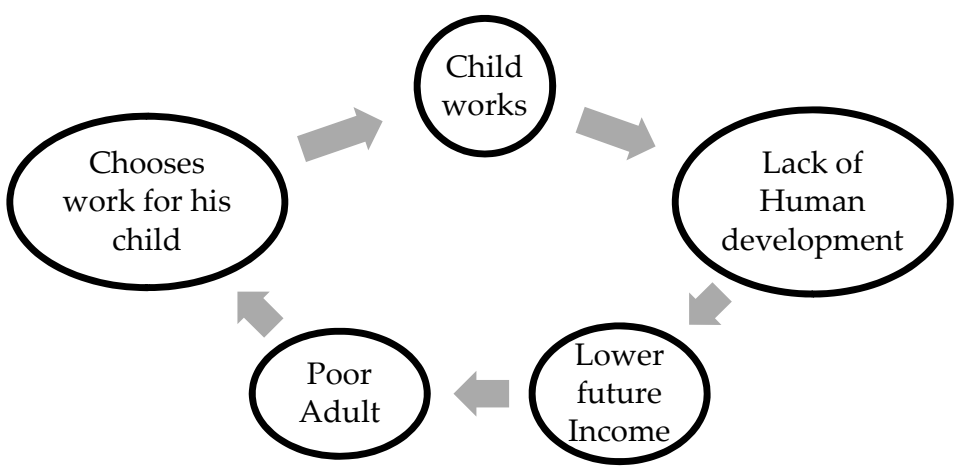

Figure B2: School attendance and domestic work (5-14 years) (\%)

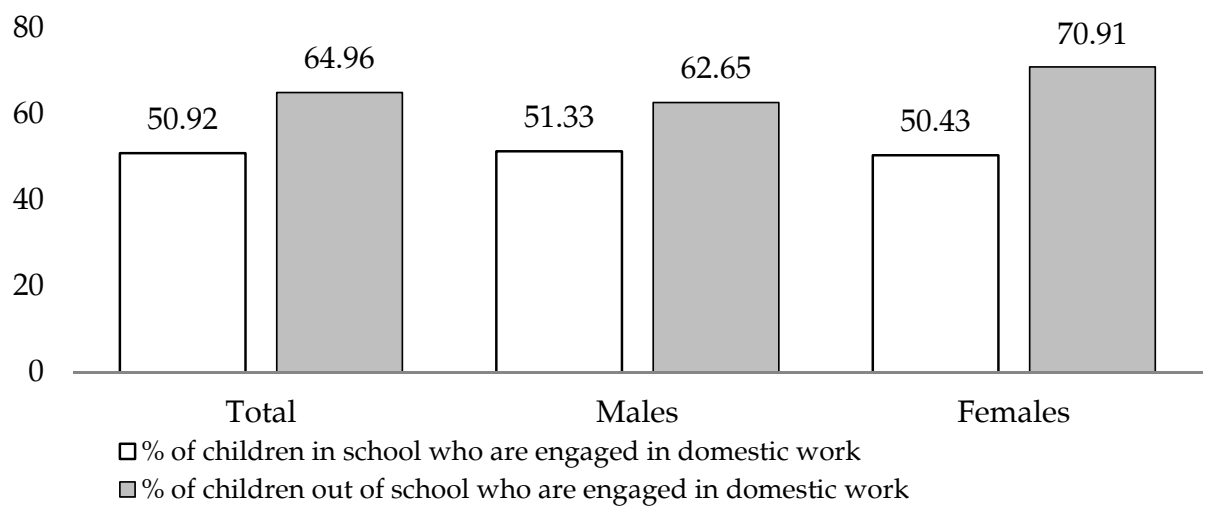

Source: Data from MICS (07-08) \& author's own calculations

Figure B3: School attendance and family work (5-14 years) (\%)

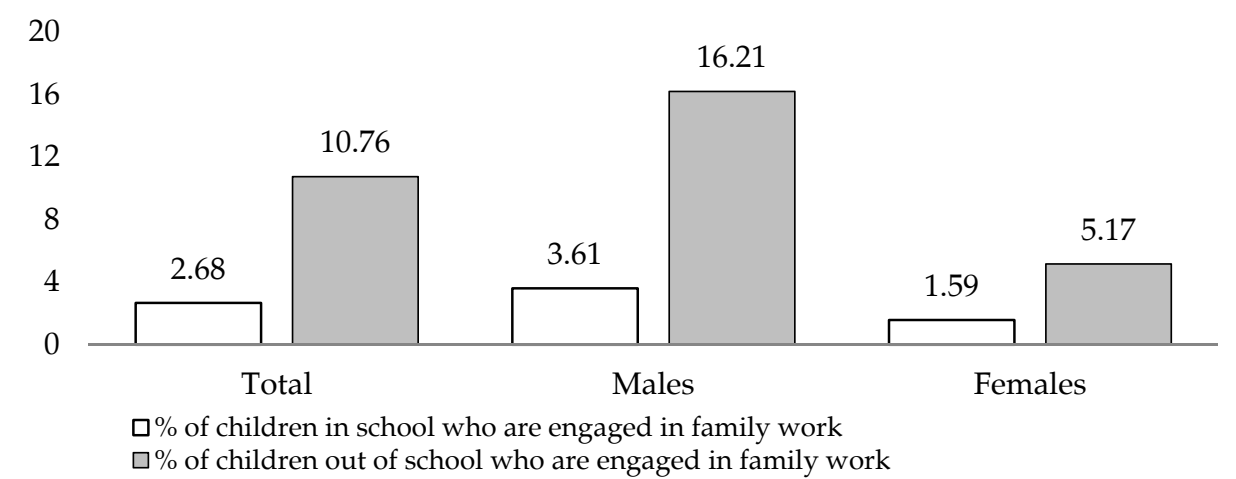

Source: Data from MICS (2007/08) and author's calculations. 


\section{Appendix C}

\section{Education Subsidies under Punjab Education Sector Reform Program}

In Pakistan, the provincial government in collaboration with the World Bank launched the Punjab Education Sector Reform Program (PESRP) in 2003, at a cost of PKR 21.7 billion (Punjab, Department of School Education, 2011). The main objective of the program was to improve the access, quality, and governance of the education sector (Solotaroff, 2007).

Under the PESRP, one of the projects was the provision of free textbooks in public schools from katchi to grade 10. This project was introduced in 2004/05. The main objective of providing free textbooks was to increase enrolment rates as well as induce lower dropout rates by reducing the cost of education. Free textbooks were given to approximately 11 million students annually.

Under the disbursement mechanism, textbooks were delivered from the Punjab Textbook Board (PTTB) to the district headquarters from where they were transferred to tehsil-level warehouses and on to union councils. The councils were then responsible for the eventual delivery of books to all public schools in that area. At the schools, the delivery of stock was undertaken in the presence of the school head. Once the books were distributed to students at the school, they became their property. Any surplus stock of books was returned by the school and followed the same channel backwards, eventually reaching the PTTB.

Other projects under PESRP included a female secondary school stipend program, the provision of toilets, boundary walls, and additional classrooms for about 30,000 schools, the hiring of 50,000 additional school teachers, provision of financing to 300 low-cost private schools using a public-private partnership model to support students from lower-income quintiles, establishment of community-based school councils in 43,000 primary schools, an increase in sector budget by almost 50 percent in a three-year period, making 1,000 closed schools functional, and instituting new arrangements for sector governance by signing performance-based monitoring and financing agreements between the province and the 35 district governments (Solotaroff, 2007).

The education sector witnessed significant improvements under the PESRP. The primary net enrolment rate in Punjab increased from 45 percent in 2001/02 to 58 percent in 2004/05 while the primary completion 
rate in government schools increased from 58 to 61 percent in the same period (based on data from the PIHS and Pakistan Social and Living Standards Measurement Survey for 2004/05). Progress was also seen toward greater gender parity. The gross enrolment ratio for girls in middle school increased from 43 to 53 percent over the three years from 2003 to 2006, and in absolute terms enrolment increased by over 60 percent (Punjab, Department of School Education, 2011).

Although the program's initial duration was up to 2006, in view of its success, it was extended for another three years. There is, however, no evidence on how this rise in school enrolment has affected child labor activities in Punjab. Against this backdrop, it is interesting to study the link between schooling and child labor. 